\title{
Relationships among Kittlitz's murrelet habitat use, temperature-depth profiles, and landscape features in Prince William Sound, Alaska, USA
}

\author{
Andrew J. Allyn ${ }^{1, *}$, Aly McKnight ${ }^{2}$, Kevin McGarigal ${ }^{1}$, Curtice R. Griffin ${ }^{1}$, \\ Katherine J. Kuletz ${ }^{2}$, David B. Irons ${ }^{2}$ \\ ${ }^{1}$ Dept. of Environmental Conservation, University of Massachusetts Amherst, Amherst, Massachusetts 1002, USA \\ ${ }^{2}$ US Fish and Wildlife Service, Anchorage, Alaska 99503, USA
}

\begin{abstract}
Although seabirds search large areas for food, their distributions often correlate with physical characteristics of the marine environment that can serve to aggregate prey. Kittlitz's murrelets Brachyramphus brevirostris are found almost exclusively in Alaskan waters, where they are closely associated with glacial fjords, suggesting that the distribution of this bird might be tightly linked to specific physical habitat characteristics of the fjords. We investigated relationships among locations used by Kittlitz's murrelets, water column characteristics, and landscape features in Harriman Fjord and Heather Bay, Prince William Sound, Alaska, USA. In Harriman Fjord, Kittlitz's murrelets were observed in shallow water near upwelling areas, indicated by a cold-water wedge near the surface ( 10 m depth) in temperature-depth profiles. In Heather Bay, Kittlitz's murrelets used locations closer to the glacial moraine than the average available habitat. The temperature-depth profiles at these locations showed a cold, fresh surface layer (near surface to $5 \mathrm{~m}$ depth); however, the temperature-depth profile variable was statistically insignificant, likely because of small sample size. Although the best temperature-depth profile variables were dramatically different between the 2 fjords, both of these glacially influenced water column characteristics may serve to concentrate prey at an optimal depth, allowing Kittlitz's murrelets to focus their effort at predictable foraging locations. Given the widespread wasting of glaciers throughout their range, Kittlitz's murrelets may face increased pressure as changes in water column dynamics within glacial fjords affect the distribution and concentration of preferred prey.
\end{abstract}

KEY WORDS: Brachyramphus brevirostris $\cdot$ Kittlitz's murrelet · Seabird habitat use · Conductivitytemperature-depth meter - Temperature-depth profile - Water column profile · Glacial moraines · Case-controlled logistic regression

\section{INTRODUCTION}

Interactions among water masses with different physical properties (e.g. temperature, salinity, pressure, and density) can create distinct horizontal and vertical gradients within the water column, which in turn influence biological patterns and processes. Horizontal gradients, or fronts, are generally mesoscale (10s to 1000 s of kilometers) patterns and are usually observed where water masses of substan- tially different densities meet (Mann \& Lazier 2006). Vertical gradients occur on smaller scales (meters to kilometers), and can result from differences in temperature or salinity, which both influence the density of the water mass (Stewart 2008). These horizontal and vertical transition zones are often highly productive areas, as the confluence of 2 or more water masses often serves to enrich depleted nutrients (Belkin et al. 2009). The high primary productivity levels and aggregations of lower trophic level species 
(e.g. macrozooplankton and forage fish) in turn attract large densities of higher trophic level organisms within and near these transition zones (e.g. Spear et al. 2001, Pelletier et al. 2012).

The productivity and survival of higher trophic level organisms, such as seabirds, are dependent upon their efficiency in locating such concentrations of prey. Therefore, although seabirds often search large areas for food, they generally congregate where there are high concentrations of prey driven by physical characteristics of the water column (Durazo 1998). Consequently, seabird densities often also correlate with these physical characteristics, including sea surface temperatures and salinities (Schneider 1990), boundaries between mixed and stratified waters (Hunt \& Schneider 1987), and tidal front areas where the body of water is confined to a limited space, causing a bottleneck effect (Day \& Byrd 1989). Bathymetric features (e.g. shallow banks, shoals, slopes, shelves), which can create secondary circulation patterns and subsequently aggregate prey (e.g. Hunt et al. 1998, Allen et al. 2001), can also attract seabirds (e.g. Hunt \& Schneider 1987, Hunt et al. 1998). The relationships between seabirds and these physical properties and landscape features likely occur because they heighten prey densities, which can serve to increase foraging efficiency (MacArthur \& Pianka 1966, Stephens \& Krebs 1986). Increased efficiency serves to maximize net energy input, resulting in better body condition and improved survival and productivity rates (Chastel et al. 1995).

The Kittlitz's murrelet Brachyramphus brevirostris, a small diving seabird of the Alcidae family, is found almost exclusively in Alaskan waters (Day et al. 1999) and is closely associated with tidewater glaciers and glacial outflow regions (Kissling et al. 2007, Stephensen 2009). Within Prince William Sound (PWS), Alaska, USA, 98\% of Kittlitz's murrelets are found in glacial fjords during the breeding season, with the remaining birds spread sparsely throughout the bays, passes and open areas (Kuletz et al. 2011). The concentration of Kittlitz's murrelets in glacial fjords of PWS suggests that the distribution of this bird may be tightly linked with specific physical characteristics that influence the distribution and abundance of preferred prey. Although we know little about the diet of Kittlitz's murrelet, sparse diet samples and bill load observations suggest that they feed on small forage fish and neritic macrozooplankton during the summer (Hobson et al. 1994, Day \& Nigro 2000). Additionally, during our study we observed Kittlitz's murrelets with bill loads of Pacific sand lance Ammodytes hexapterus and Pacific herring Clupea pallasi at the surface (A. J. Allyn \& A. McKnight pers. obs.). These observations suggest that these fish species are likely important prey for Kittlitz's murrelets in our study area; however, we were not able to observe consumption of euphausiids, amphipods, or other macrozooplankton.

The association between the distribution of Kittlitz's murrelets and tidewater glacier ecosystems may exacerbate the risk of increased population declines caused by habitat degradation. In addition to the unique physical features characteristic of tidewater glacial fjords (e.g. shallow sills, moraines, and deep basins), these ecosystems also experience dynamic external influences. Such influences, including tidal action, calved icebergs, and variable run-off from sediment-laden freshwater streams, can substantially affect the physical characteristics of the water column, in turn influencing the distribution and composition of biological communities (Etherington et al. 2007, Arimitsu et al. 2012). Before we make any attempt to mitigate recent widespread population declines of Kittlitz's murrelets in Alaska (Arimitsu et al. 2011, Kuletz et al. 2011, Piatt et al. 2011) it is imperative that we gain a better understanding of the factors that affect Kittlitz's murrelet distributions in these glacial fjord systems. Therefore, in the present study, we investigated the habitat use of Kittlitz's murrelets in July 2008 in Harriman Fjord and Heather Bay -2 fjords in PWS with exceptionally high densities of Kittlitz's murrelets - in relation to temperature-depth profiles and landscape features.

\section{MATERIALS AND METHODS}

\section{Study area}

Prince William Sound is a large, glaciated embayment located in south-central Alaska (Fig. 1) that includes $5000 \mathrm{~km}^{2}$ of shoreline (marine habitat within $200 \mathrm{~m}$ of land) and approximately $9000 \mathrm{~km}^{2}$ of water surface area. PWS is surrounded by the Chugach National Forest, which contains $21320 \mathrm{~km}^{2}$ of glaciers and ice fields with approximately 20 tidewater glaciers that terminate in PWS (Molnia 2007). Abundant freshwater inputs, as well as glacial outflows of freshwater, silt, and ice, have profound effects on this marine ecosystem, particularly during the summer months. During July and August, water temperatures are warmest and surface salinities lowest (Cooney et al. 2001). PWS waters have a diurnal $6 \mathrm{~m}$ tidal cycle, 


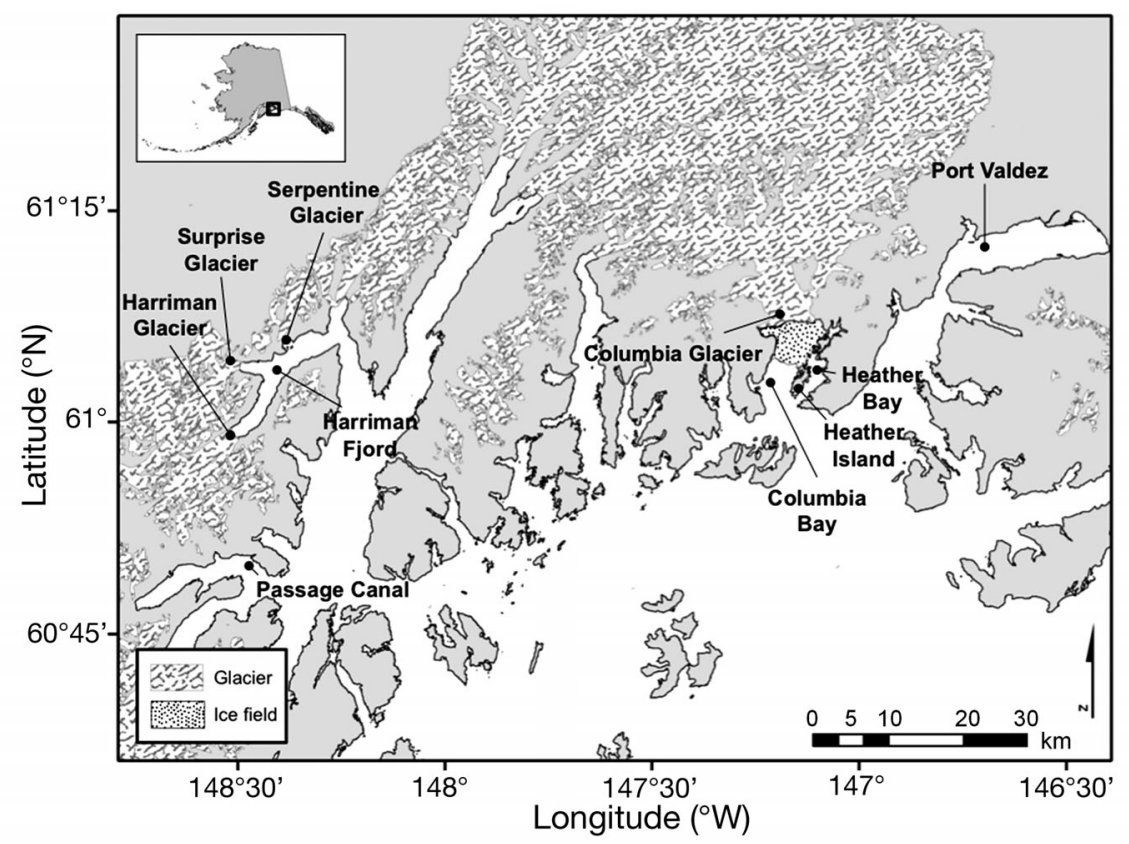

Fig. 1. Northern Prince William Sound, Alaska (inset), USA, showing Heather Bay and Harriman Fjord study areas and relevant landscape features
Heather Bay contains no tidewater glaciers, only Heather Island and an exposed glacial moraine separate it from Columbia Bay. The exposed moraine is never completely submerged, but water flows into Heather Bay from Columbia Bay over the moraine at several locations during each incoming tide. Columbia Bay has extraordinarily high densities of icebergs because of the damming effect of a submerged moraine near the entrance to its fjord. Thus, the large tidal influx of water from Columbia Bay carries large amounts of ice into Heather Bay. Kittlitz's murrelet numbers in Heather Bay appear to exhibit a great deal of annual variability. In 2007, during US Fish and Wildlife Service marine bird and mammal surveys (sound-wide, randomly selected transects), $75 \%$ of the Kittlitz's murrelets observed in PWS were located in Heather Bay (Kuletz et al. 2011). During intensive surveys in 2009 (systematic transects in known Kittlitz's murrelet habitat), Heather Bay accounted for roughly $5 \%$ of the Kittlitz's murrelets observed (Kuletz et al. 2011).

\section{Data collection}

\section{At-sea surveys}

We surveyed Harriman Fjord and Heather Bay 3 times each during July 2008, in the chick-rearing phase of Kittlitz's murrelet breeding chronology (Day et al. 1999, Kaler et al. 2009). We used fjord-specific sampling grids stratified into areas of high and low Kittlitz's murrelet density based on surveys conducted by Allyn et al. (2008) and Stephensen (2009). We surveyed a different subset of available transects during each visit to each fjord (mean $=5$ transects per visit, range $=4$ to 7 transects) (Table A1 in the Appendix) .

In Harriman Fjord, our sampling grid included 6 transects, with 4 transects in the high density area and 2 transects in the low density area (Fig. 2A). Transects varied in length from 1000 to $2000 \mathrm{~m}$ and were separated by $450 \mathrm{~m}$. Because of the geography of Harriman Fjord, transects ran east-west to align sampling with the dominant physical force in the sampling region: ice and glacial outflow from Surprise Glacier. tidewater glacier (Molnia 2007) (Fig. 1). Although 

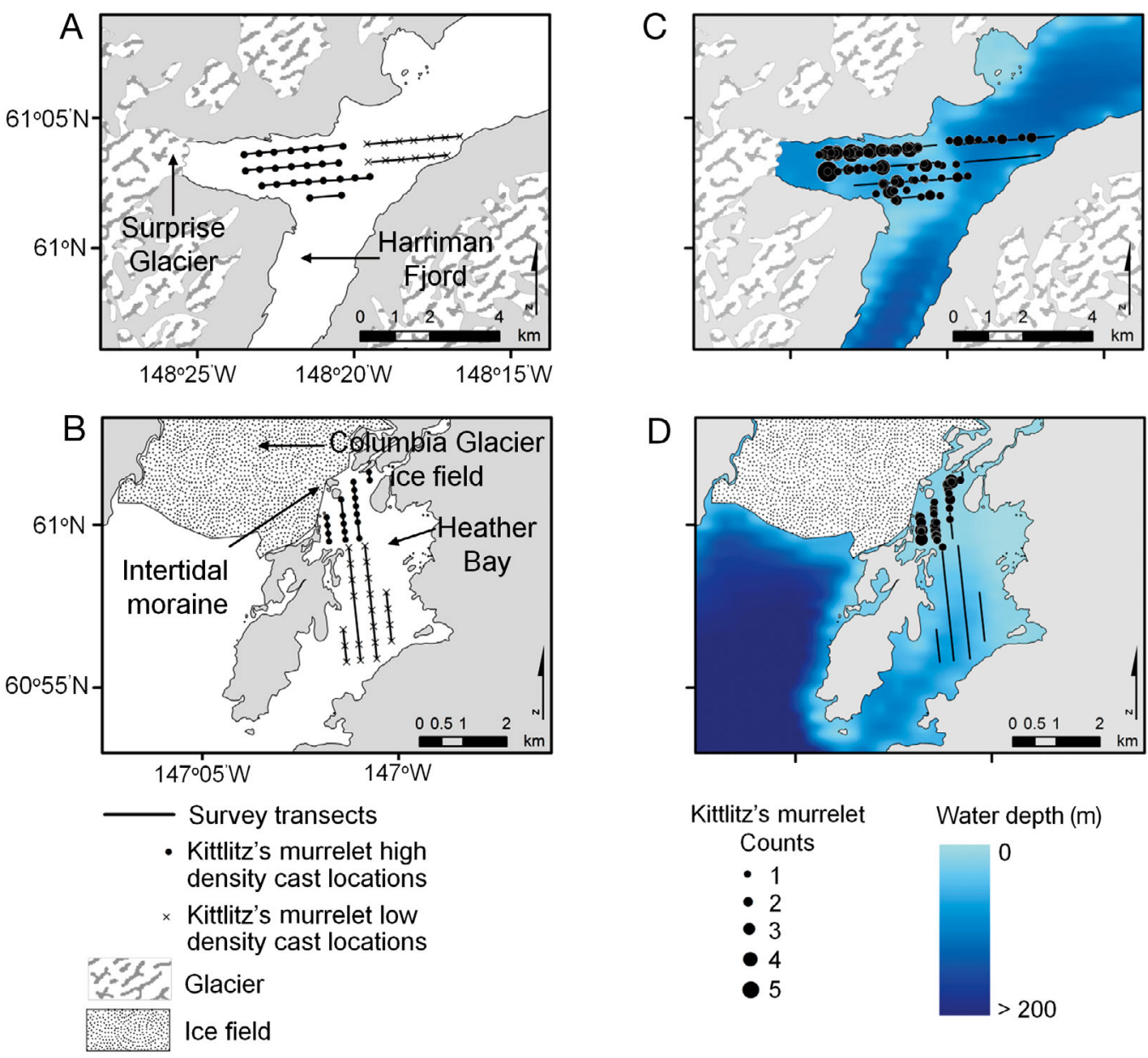

Fig. 2. Survey transects, Kittlitz's murrelet high and low density CTD cast locations in (A) Harriman Fjord and (B) Heather Bay, and distribution and abundance of Kittlitz's murrelets observed on 3 surveys in (C) Harriman Fjord and (D) Heather Bay, Prince William Sound, Alaska, July 2008

In Heather Bay, our survey grid included 8 transects, with 4 in the high density area and 4 in the low density area (Fig. 2B). High density transects were separated by $400 \mathrm{~m}$ and had lengths ranging from 200 to $1300 \mathrm{~m}$. Low density transects were separated by $400 \mathrm{~m}$ and had lengths ranging from 745 to $2600 \mathrm{~m}$. We surveyed Heather Bay transects in the north-south direction to align sampling with the dominant physical force in the bay: ice flowing over the moraine at the northern reaches of the bay.

While surveying along transects in both areas, 2 observers using $10 \times$ binoculars recorded all marine birds and mammals observed within $100 \mathrm{~m}$ to either side and in front of the $7 \mathrm{~m}$ survey vessel traveling at 10 to $15 \mathrm{~km} \mathrm{~h}^{-1}$. We assumed $100 \%$ detection within this $200 \mathrm{~m}$ wide survey strip. Observers were thoroughly trained in murrelet identification and distance estimation. We entered sighting and behavior (e.g. 'floating,' 'foraging,' 'flying,' etc.) data in real time onto a laptop computer running Program dLOG (Glenn Ford Consulting). A connected handheld GPS unit (Garmin GPSMAP-76) stamped each sighting with geographical coordinates according to the boat's location as well as documenting the path of the survey vessel. Birds recorded in groups were assigned a single location (i.e. if we recorded a group of 3 birds together on the water, we assigned the same location to all 3). We did not include flying birds in our habitat use analysis, as we were unable to determine the exact locations where they took off or landed.

\section{At-sea water column sampling}

After completing our visual survey of each transect, we returned along the transect to deploy the CTD meter (SBE 19 SEACAT, SeaBird Electronics) at pre- 
determined cast locations. Cast locations were separated by $400 \mathrm{~m}$ in Harriman Fjord (Fig. 2A) and by $200 \mathrm{~m}$ in Heather Bay (Fig. 2B). All CTD casts were completed within $1.5 \mathrm{~h}$ of the end of the visual survey of that transect. The CTD meter was suspended just below the surface and allowed to equilibrate for $2 \mathrm{~min}$ before being lowered to within $2 \mathrm{~m}$ of the ocean floor. Depths at each cast point were determined using an on-board depth finder (LMS-350A, Lowrance). We set the sampling rate of the CTD meter to sample water temperature, salinity, density, and depth twice per second.

We used Seabird Electronics Data Processing software (version 7.16) to process the raw CTD data files. First, we split the data into upward and downward portions of the casts. Next, we filtered the data from the downward portion of the cast to smooth rapidly changing data over a forward and backward gradient (Seabird Electronics 2012). We used only data from down casts because these data were collected before the water column was disturbed by the passage of the CTD meter.

We truncated the temperature-depth data at $25 \mathrm{~m}$ depth based upon foraging studies of the closely related marbled murrelet Brachyramphus marmoratus. Marbled murrelet generally forage in waters $<20 \mathrm{~m}$, only occasionally reaching depths $>30 \mathrm{~m}$, with dive times around $25 \mathrm{~s}$ (Jodice \& Collopy 1999). The average dive time of Kittlitz's murrelets foraging in Harriman Fjord in 2009 was $22 \mathrm{~s}$ (95\% CI = 18.5 to 25.4), and surfacing birds almost always appeared tens of meters away from the location where they originally submerged, suggesting that individuals do not typically dive deep in these areas (A. J. Allyn unpubl. data). We estimated near-surface temperatures using the average water column temperatures recorded during the equilibration period when the CTD was roughly $1 \mathrm{~m}$ below the surface. Finally, because we were interested in relative temperature profile patterns rather than absolute temperatures, we subtracted each recorded temperature from the near-surface temperature for that cast to determine the relative temperatures at each depth with respect to the surface temperature.

\section{Spatial landscape features}

We calculated spatial landscape feature values for used and available habitat locations. We defined 'used habitat' as the longitude and latitude location recorded for each Kittlitz's murrelet observed during surveys, and 'available habitat' as the area encom- passing all transects surveyed during each individual visit to the fjord (i.e. a minimum convex polygon of all transects, with a $100 \mathrm{~m}$ buffer to include the survey window on the outer edge of the transects). Therefore, the available habitat area varied between visits to a fjord because not all transects were surveyed during each visit. We sampled the available habitat by creating a $100 \times 100 \mathrm{~m}$ grid over each fjord using ArcGIS version 9.3 (ESRI 2008); we then extracted the latitude and longitude centroid for each grid cell and used these locations to represent available habitat.

We used R (R Core Development Team 2010) to calculate 5 spatial landscape features for each used and available location: water depth, and distances to shoreline, glaciers, moraines, and freshwater streams/outflows. We created a water depth raster layer, measured on a negative scale where the surface was defined as $0 \mathrm{~m}$ and $20 \mathrm{~m}$ depth was defined as $-20 \mathrm{~m}$ from a PWS bathymetry ASCII file (resolution: $200 \mathrm{~m}$ ) (D. A. Kiefer unpubl. data). Using this bathymetry file in combination with NOAA charts, we also identified submerged moraines as shallow (0 to $30 \mathrm{~m}$ ) arms extending into and/or across fjords or bays. Satellite images (US Geological Survey Global Visualization Viewer Landsat Archive) from July 2008 provided the terminus location of each tidewater glacier. We defined the shoreline and locations of freshwater streams using a data layer provided by the US Forest Service (USDA Forest Service 2008). We interpolated depth values for each used and available point from the bathymetry raster file (D. A. Kiefer unpubl. data) using the inverse distance weighting function in the gstat package (Pebesma 2004). We used the nncross function in the spatstat package (Baddeley \& Turner 2005) for all distance calculations. We used the shortestPath function in the gdistance package (van Etten 2011) for all over-water distance calculations. We restricted distances to the over-water distance between a point and landscape feature (glaciers, moraines, and outflow regions) by setting the land conductance value to 0 and the ocean conductance value to 1 .

\section{Data analysis}

At-sea surveys: Kittlitz's murrelet abundance, time of day, and tide level and phase

We modeled Kittlitz's murrelet abundance within Harriman Fjord and Heather Bay as a function of time of day, average tide level height $(\mathrm{m})$, and tide phase using a generalized linear model (GLM) with a 
Poisson error distribution and log link. We used the abundance model to investigate the influence of time of day and tide on predicted counts of Kittlitz's murrelets, independent of temperature-depth profiles and landscape features. This allowed us to then use the full collection of CTD casts collected during a visit to characterize the available habitat with regard to temperature-depth profiles, as described below.

We calculated Kittlitz's murrelet abundance by summing the number of Kittlitz's murrelets counted during 12 min intervals. We assigned the time of day for each observation as the median time per $12 \mathrm{~min}$ interval from the associated time stamp output from the program dLOG and the attached GPS device. We used tide prediction data in the mean tide level datum (mean of mean high water and mean low water, NOAA Tides and Currents, http://co-ops.nos. noaa.gov/tide_predictions.shtml) to calculate the average tide level height (m) for each 12 min time interval. We used tide data from Passage Canal predictions ( $\sim 35 \mathrm{~km}$ to the southwest) for Harriman Fjord, and Port Valdez predictions $(\sim 40 \mathrm{~km}$ to the northeast) for Heather Bay tide level heights. We evaluated both linear and quadratic relationships between time of day and tide level height and Kittlitz's murrelet abundance.

In addition to tide level height, we also included tide phase in our abundance model. We defined 6 different tide phases: slack low and high, incoming low and high, and outgoing low and high. Slack low and high tide phases were defined as 30 min before and after dead low and high tide. We calculated incoming low and high and outgoing low and high using the midpoint tide level height (m) for a given tidal cycle. For example, an incoming low tide phase corresponded to an incoming tide, where the observed tide level height had not yet surpassed the midpoint tide level height for that incoming tide cycle. Our full abundance model was:

$$
\begin{gathered}
\log (p)=\alpha+\beta_{1} \times \text { time of day }+\beta_{2} \times \text { time of day }^{2} \\
+\beta_{3} \times \text { tide level height }+\beta_{4} \times \text { tide level height }^{2} \\
+\beta_{5} \times \text { tide phase }+\beta_{6} \times \text { fjord }
\end{gathered}
$$

To evaluate model subsets, we first examined the results from the full model to identify significant parameters. We then dropped any insignificant parameters, tested for interactions between significant model parameters in the reduced GLM, and selected the best model based on corrected Akaike's information criterion (AICc). The predicted abundance from the best model was then used as a weighting function in our calculation of each average available temperature-depth profile value, as described below.

\section{Temperature-depth profiles}

Calculating temperature-depth profile values at used and available habitat locations required significant analyses to overcome 2 challenges: (1) summarizing the temperature-depth profile data into a single metric that could be included in the overall habitat use model, and (2) calculating this metric for both used and available locations that did not coincide either spatially or temporally with locations of CTD casts.

Summarizing CTD data into a single metric. Standard modeling frameworks require one-to-one relationships between the response and a given predictor variable, so that for a given response observation there is a single corresponding predictor value. However, temperature-depth data collected by a CTD meter contains a large number of temperature and depth values for every cast. There are a number of ways to summarize these data into a single value, including averaging over selected depth bins, or calculating the depth of the maximum temperature change (e.g. Speckman et al. 2005). However, as we were interested in capturing the overall structure of the temperature-depth profile, we chose to develop our own summary method by calculating individual deviance values from the observed temperaturedepth data and a number of proposed temperaturedepth profile shapes (TDPS). This process allowed us to reduce CTD temperature-depth measurements into a single metric that could be included as a variable in our habitat use model. We then selected the best TDPS by individually calculating the negative log likelihood for the habitat use model and each of the TDPSs; the TDPS that maximized the negative log likelihood of the habitat use model indicated the TDPS that was most similar to the structure of temperature-depth profile where Kittlitz's murrelets were observed.

We used a piece-wise linear function with 3 segments to create the suite of proposed TDPSs. Specifically, we varied the slope of the 3 segments by changing the depth and temperature between the start and end of each segment, resulting in a total of 1500 TDPSs (Table A2 in the Appendix). We then calculated an overall deviance between the TDPSs and the observed temperature-depth profile data at each cast location. For an individual TDPS and CTD cast, we first calculated residuals at each observed depth by subtracting the relative observed temperature from the predicted temperature calculated using the piece-wise linear function. Lastly, we summed all squared residual values and divided by the number 
of samples (i.e. observed depths) to calculate an overall cast deviation value between an individual TDPS and observed temperature-depth profile data. This process generated a data frame, where the number of rows was equal to the number of casts completed, each column of the data frame corresponded to a different TDPS, and cell values indicated the overall deviation between the TDPS and the observed temperature-depth data for the given cast.

Accounting for spatial and temporal mismatch between casts and observations. After calculating deviation values between each cast and all TDPSs, we needed to calculate TDPS deviation values for used locations. This was done using the inverse distance weighting function in the gstat package (Pebesma 2004). For a given bird observation, we used only the TDPS deviation values from CTD casts collected along the same transect on which the bird was observed for interpolation, and therefore, assumed that temperature-depth data were relatively constant over a $1.5 \mathrm{~h}$ period (i.e. the time between the first bird observation along a transect and the last cast on the same transect). This yielded the most accurate estimate of the TDPS deviation value for a given location. We repeated this procedure to calculate the deviation between each used location and each of the 1500 TDPSs.

Calculating TDPS deviation values for the average available habitat was a more complex process than for the used locations. To calculate these deviation values, we needed to account for the significant difference between the times of day and tides that CTD casts were completed within a given survey. If we simply averaged TDPS deviation values without accounting for this variability, this would assume that (1) temperature-depth data were constant throughout each sampling period, most of which spanned $>6 \mathrm{~h}$ and entire tidal cycles, and (2) that all Kittlitz's murrelets were exposed to the same available habitat conditions regardless of when they were observed. This is likely not the case given the influence of time of day and tide on water column characteristics, currents, and the temporal distribution of Kittlitz's murrelets. Unfortunately, our CTD data set was insufficient for modeling changes in TDPS deviation values as a function of time and tide. Consequently, we used our bird observation data and the resulting Poisson abundance model (Eq. 1) to quantify the relationship between predicted Kittlitz's murrelet count, time of day, and tide level and phase. Using this function to weight TDPS deviation values, we were able to use all CTD casts collected throughout the day to calculate an average TDPS deviation value for each pro- posed shape. We assumed that this technique provided an estimation of the range of TDPSs available to birds over the course of each sampling period.

To weight the TDPS deviation values, we first multiplied each of the 1500 deviation values for each cast by the predicted Kittlitz's murrelet count for that time of day and tide phase according to the GLM Kittlitz's murrelet abundance model. We then summed all weighted TDPS deviation values by day, and divided the sum of all weighted TDPS deviation values by the sum of all predicted Kittlitz's murrelet counts to generate the TDPS deviation values that would represent the average available habitat in each sampling area. For each sampling session, this yielded a weighted average TDPS deviation value that accounted for the variation in predicted Kittlitz's murrelet counts dependent on time of day and tide phase.

Kittlitz's murrelet habitat use

To investigate Kittlitz's murrelet habitat use, we modeled the difference in each habitat variable between used locations and the average available habitat. To calculate these differences between TDPS deviation values, for each of the 1500 TDPSs, we paired the TDPS deviation values for each used point with the average TDPS value among all available points within the same fjord. This means that for each of the 1500 TDPSs, we subtracted the weighted TDPS deviation value representing the average available habitat from the interpolated TDPS values at used points within that sampling region. If the resulting value was positive for a given TDPS, this indicated that the TDPS fit the average available habitat well, but fit the used locations poorly. We therefore removed candidate TDPSs that yielded positive values from our analysis. For landscape features, we first averaged all the available habitat values for each variable within each fjord. We then subtracted each average value from the corresponding used covariate value for each location. This process generated a file containing a line for every Kittlitz's murrelet observation that included a column for the difference in used and average available TDPS deviation values for each of the 1500 proposed TDPSs and the difference in used and average available values for each of the 5 landscape features.

We then used a GLM with a binomial error distribution and logit link function (Breslow \& Day 1980) to investigate the difference between used and available Kittlitz's murrelet habitat in a case-controlled 
logistic regression model. Unlike traditional logistic regression, where the response variable is presence/ absence, in case-controlled (also known as paired or conditional) logistic regression the response variable is only presence and a 'no intercept' model is used (e.g. Compton et al. 2002). We used Firth's biasreduction method as implemented in the brglm package (Kosmidis 2010), where parameters were estimated using maximum penalized likelihood. Harriman Fjord and Heather Bay were modeled separately to allow for differences between fjords that may influence TDPSs (e.g. bathymetry, glacier influences, etc.). For Harriman Fjord, our full model was:

$$
\begin{aligned}
& \text { Logit }(\mathrm{p})=F_{1} \times \text { depth }+F_{2} \times \text { dist. shore } \\
& +F_{3} \times \text { dist. glacier }+F_{4} \times \text { dist. moraine } \\
& \quad+F_{5} \times \text { dist. stream }+F_{6} \times \text { TDPS }
\end{aligned}
$$

For Heather Bay, our full model was:

$$
\begin{aligned}
& \text { Logit }(\mathrm{p})=B_{1} \times \text { depth }+B_{2} \times \text { dist. shore } \\
& +B_{3} \times \text { dist. moraine }+B_{4} \times \text { dist. stream } \\
& +B_{5} \times \text { TDPS }
\end{aligned}
$$

where dist. is the distance to geographical features. Distance to glacier was not included in the Heather Bay GLM (Eq. 3) because of strong correlation with distance to moraine. The terminus of Columbia Glacier is located over $12 \mathrm{~km}$ beyond the head of Heather Bay. Given that the intertidal moraine is also located at the head of Heather Bay, distance to glacier was strongly correlated with distance to moraine. Although both features certainly influence the Heather Bay marine habitat, we elected to use only 'distance to moraine' in the Heather Bay GLM.

We selected the best TDPS by comparing negative log-likelihood values among GLMs with all landscape features while varying only the temperature-depth candidate variable. Because the number of parameters was constant across all models, the TDPS that minimized the negative log-likelihood (i.e. maximized the likelihood) of the GLM was used as our best estimate of the temperaturedepth profile at Kittlitz's murrelet use locations. We then investigated the full range of model subsets, using the best TDPS and all landscape feature covariates.

We suspected that GLM residuals might be spatially autocorrelated in response to the patchy distribution of Kittlitz's murrelets in PWS. Recogniz- ing that there is still not a formal, well-established test for spatial autocorrelation of GLM residuals (R. Bivand pers. comm.), we tested model residuals for spatial autocorrelation using the lm.moran test function in the spdep package (Bivand et al. 2012).

\section{RESULTS}

\section{Kittlitz's murrelet abundance, time of day, and tide height}

We observed 137 Kittlitz's murrelets in Harriman Fjord (Fig. 2C) and 58 Kittlitz's murrelets in Heather Bay (Fig. 2D). Overall, the mean density (birds km${ }^{-2}$ ) among visits was similar for the 2 fjords; however, the density variability among trips was considerably smaller in Harriman Fjord (mean $=23.29, \mathrm{SD}=16.22$ birds $\mathrm{km}^{-2}$ ) than that in Heather Bay (mean $=25.33$, $\mathrm{SD}=37.72$ birds $\mathrm{km}^{-2}$ ).

Time of day, tide phase, and an interaction between time of day and tide phase significantly influenced Kittlitz's murrelet abundance (Table 1), and were parameters of the best model predicting Kittlitz's murrelet abundance $(\mathrm{AICc}=249.13$, AICc weight $=$ $0.83)$. The predicted mean count of Kittlitz's murrelets per 12 min interval in a fjord decreased throughout the day, and during slack low and outgoing low tide phases, and increased during incoming high tide phases. The best model with linear terms for time of day and tide phase and an interaction term between time of day and tide phase was used as our function for weighting TDPS deviation values.

Table 1. Point estimates, standard errors (SE) and probability values ( $p$ ) of parameters included in the best generalized linear model as selected by corrected Akaike's information criterion (AICc) describing Kittlitz's murrelet abundance in Heather Bay and Harriman Fjord, Alaska, July 2008. Tide phases: $\mathrm{IL}=$ incoming low, $\mathrm{OH}=$ outgoing high, $\mathrm{OL}=$ outgoing low, $\mathrm{SH}=$ slack high, $\mathrm{SL}=$ slack low

\begin{tabular}{|lrrrl|}
\hline Parameter & Estimate & SE & Z-statistic & $\mathrm{p}(>|Z|)$ \\
\hline Intercept & 5.32 & 1.32 & 4.02 & $5.84 \times 10^{-5}$ \\
Time of day & -0.32 & 0.11 & -3.02 & 0.0025 \\
Tide phase IL & -0.18 & 3.68 & -0.05 & 0.96 \\
Tide phase OH & -1.95 & 1.84 & -1.06 & 0.29 \\
Tide phase OL & -4.29 & 1.61 & -2.66 & 0.0078 \\
Tide phase SH & -3.34 & 2.59 & -1.29 & 0.20 \\
Tide phase SL & -5.93 & 2.64 & -2.25 & 0.024 \\
Time of day $\times$ tide phase IL & -0.15 & 0.32 & -0.49 & 0.63 \\
Time of day $\times$ tide phase OH & 0.05 & 0.15 & 0.31 & 0.75 \\
Time of day $\times$ tide phase OL & 0.26 & 0.13 & 2.09 & 0.036 \\
Time of day $\times$ tide phase SH & 0.24 & 0.18 & 1.34 & 0.18 \\
Time of day $\times$ tide phase SL & 0.44 & 0.22 & 1.97 & 0.049 \\
\hline
\end{tabular}



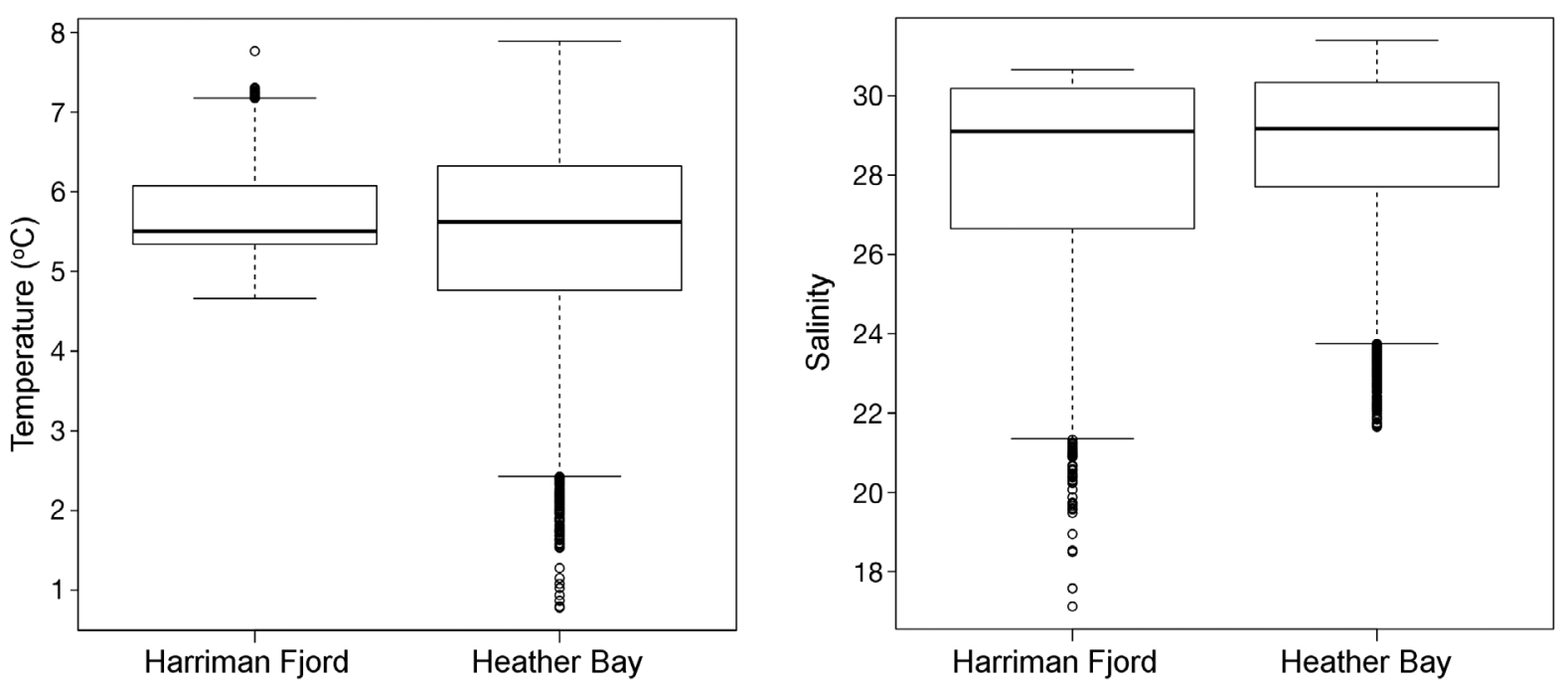

Fig. 3. Summary plots of temperature and salinity values recorded on CTD casts during surveys in Harriman Fjord and Heather Bay, Alaska, July 2008. Horizontal lines within boxes indicate data median, rectangular boxes indicate the interquartile ranges (i.e. $50 \%$ of the data), whiskers indicate extreme values out to a maximum of 1.5 times the interquartile range, and data points outside these range are indicated by open circles

\section{Overview of water column properties}

Although average temperatures between Harriman Fjord $\left(5.69^{\circ} \mathrm{C}\right)$ and Heather Bay $\left(5.46^{\circ} \mathrm{C}\right)$ were very similar, there was less variability in the temperatures recorded in Harriman Fjord (range $=4.66$ to $7.77^{\circ} \mathrm{C}$ ) than in Heather Bay (range $=0.78$ to $7.89^{\circ} \mathrm{C}$ ) (Fig. 3). Additionally, in Harriman Fjord the coldest water was found at maximum depths $(25 \mathrm{~m})$, and in Heather Bay the coldest water was at the surface.

Overall, average salinities in Harriman Fjord (28.1) were slightly lower than those in Heather Bay (30.3) (Fig. 3). Further, the range in salinity values was greater in Harriman Fjord (range $=17.1$ to 30.7 ) compared to Heather Bay (range = 21.7 to 31.4 ). Lastly, density profiles across CTD casts in both Harriman Fjord and Heather Bay showed increasing density with increasing water depth, where the least dense water was always on top of more dense water masses, suggesting that the relative temperaturedepth patterns we observed were stable.

\section{Kittlitz's murrelet habitat use}

\section{Harriman Fjord}

In Harriman Fjord, the best TDPS decreased by $2^{\circ} \mathrm{C}$ relative to the near surface temperature between the surface and $10 \mathrm{~m}$, and then increased by $6^{\circ} \mathrm{C}$ between 10 and $20 \mathrm{~m}$, finally cooling with increased depth beyond $20 \mathrm{~m}$ (Fig. 4A). Before evaluating all model subsets of the global GLM, we investigated the spatial autocorrelation of Kittlitz's murrelet observations in the global GLM residuals. Global GLM residuals were not significantly spatially autocorrelated (observed Moran's $I=0.23, \mathrm{p}=0.209$ ). Therefore, we proceeded to evaluate all model subsets and did not use methods to account for, or remove, spatial autocorrelation.

Overall, the best GLM describing Kittlitz's murrelet habitat use in Harriman Fjord included depth, distance to shore, distance to moraine, and TDPS as model variables (Table 2). Kittlitz's murrelets appeared to use locations that were shallower, farther from shore, and farther from the moraine than the average available habitat (Table 3, Fig. 5).

\section{Heather Bay}

In Heather Bay, the best TDPS suggested that Kittlitz's murrelets used habitats where the water column temperature increased moderately relative to the near surface temperature down to $5 \mathrm{~m}$ depth, and then decreased rapidly with increasing depths (Fig. 4B). However, because the distribution of Kittlitz's murrelets in Heather Bay was extremely patchy, and all Kittlitz's murrelets were observed closer to the moraine than the average available habitat, distance to moraine masked the potential significance of TDPS and the other landscape feature variables (Table 4). 

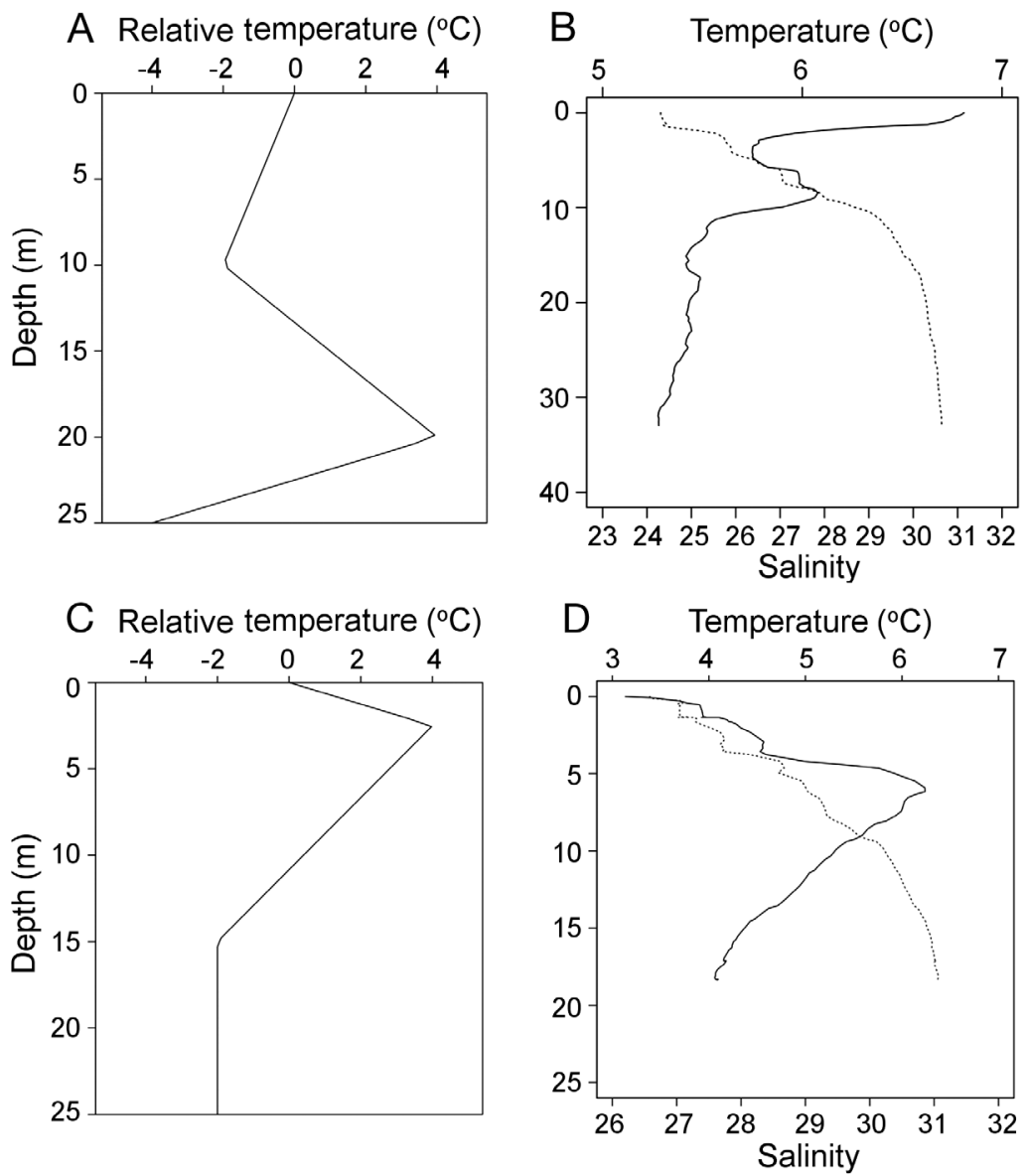

Fig. 4. Temperature-depth profile shapes (TDPSs) as selected by negative log-likelihood values describing Kittlitz's murrelet habitat use in (A) Harriman Fjord and (C) Heather Bay, Alaska, July 2008. Example raw temperature (solid line) and salinity (dotted line) data from casts in each fjord showing (B) the characteristic 'cold wedge' prevalent in the best model describing Kittlitz's murrelet habitat use in Harriman Fjord, and (D) the cold, fresh water layer remaining at the surface of the water column in the best model describing Kittlitz's murrelet habitat use in Heather Bay

Before removing distance to moraine from the model to investigate the relative significance of the other variables, we tested for spatial autocorrelation in the global GLM residuals. The spatial autocorrelation in Heather Bay GLM residuals was insignificant (observed Moran's $I=0.73, \mathrm{p}=0.072$ ). Therefore, we continued model subset investigations without removing or accounting for spatial autocorrelation.

After removing the highly significant distance to moraine variable from the model, both water depth and distance to shore became significant parameters describing Kittlitz's murrelet habitat use in Heather Bay. Kittlitz's murrelets appeared to use shallower waters at locations closer to shore than the average available (Table 4, Fig. 6). TDPS remained insignificant, and there was no clear association between locations used by Kittlitz's murrelet and distance to freshwater outflow areas (Table 4, Fig. 6).

\section{DISCUSSION}

Our results agree with previous work showing that time of day, tide phase, and landscape features influence the abundance and distribution of Kittlitz's murrelets in glacial fjords in PWS (Kuletz et al. 2003, Allyn et al. 2008, Stephensen 2009). Kittlitz's murrelet abundance appeared to be highest earlier in the day and during the incoming high tide phase. This daily pattern is similar to that observed in studies of the congeneric marbled murrelet (Speckman et al. 2000, Peery et al. 2009). Increased abundance and activity during morning hours could indicate that Kittlitz's murrelets are responding to the diurnal movements of potential prey species that feed at the surface at night and migrate to inaccessible water depths during daylight hours; these species may be most sus-

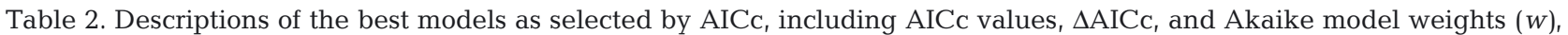
describing Kittlitz's murrelet habitat use in Harriman Fjord, Alaska, July 2008. TDPS = temperature-depth profile shape

\begin{tabular}{|c|c|c|c|}
\hline Model & $\mathrm{AICC}$ & $\triangle \mathrm{AICC}$ & $w$ \\
\hline Depth + distance to shore + distance to moraine + TDPS & 24.97 & 0 & 0.49 \\
\hline Depth + distance to shore + distance to moraine + distance to glacier + TDPS & 26.63 & 1.66 & 0.21 \\
\hline Depth + distance to shore + distance to moraine + distance to stream + TDPS & 26.92 & 1.96 & 0.18 \\
\hline $\begin{array}{l}\text { Depth + distance to shore + distance to moraine + distance to glacier } \\
\text { + distance to stream + TDPS }\end{array}$ & 27.90 & $\begin{array}{r}2.93 \\
1008\end{array}$ & 0.11 \\
\hline Depth + distance to glacier + distance to moraine + distance to stream + TDPS & 44.61 & 10.08 & 0.003 \\
\hline
\end{tabular}


Table 3. Point estimates, SE, and probability values of parameters included in the best generalized linear model as selected by AICc describing Kittlitz's murrelet habitat use in Harriman Fjord, Alaska, July 2008

\begin{tabular}{|lrrrl|}
\hline Parameter & Estimate & SE & $\begin{array}{c}Z- \\
\text { statistic }\end{array}$ & $\mathrm{p}(>|Z|)$ \\
\hline Depth & 0.44 & 0.12 & 3.64 & 0.00028 \\
Distance to shore & 31.03 & 10.17 & 3.05 & 0.0023 \\
Distance to moraine & 6.85 & 1.92 & 3.56 & 0.00037 \\
TDPS & 3.72 & 1.17 & 3.18 & 0.0015 \\
\hline
\end{tabular}

ceptible to predation during these transition periods (i.e. dawn and dusk) (Hobson 1986). Other researchers noted the correlation between Kittlitz's murrelet abundance and tide phase (here, incoming high tides) (Kissling et al. 2007, Allyn et al. 2008), suggesting that tide current strength and tide phase also influence Kittlitz's murrelet abundance. Stronger tidal currents, such as those occurring during the midpoint between high and low tides, can concentrate potential prey species more effectively than weaker currents (Alldredge \& Hamner 1980). When coupled with bathymetric features (e.g. shoals, sills, banks), there is potential for increased prey concentrations from both tidal upwelling and secondary circulation patterns resulting from the flow of water masses around these features (e.g. Hunt et al. 1998, Allen et al. 2001). Such locations and conditions would likely also exhibit dynamic water column characteristics as a result of the interactions among different water masses caused by the coupling of water flow with bathymetric features.

It appears that the interaction between tide phase and landscape features drives TDPSs and ultimately influences habitat use locations for Kittlitz's murrelet. In Harriman Fjord, we found that TDPS significantly influenced Kittlitz's murrelet habitat use. Although the TDPS variable was insignificant in Heather Bay, likely due to our small sample size, the best TDPS selected using negative log-likelihood values suggests that the TDPS at locations used by Kittlitz's murrelets were markedly different between fjords.

The TDPSs in both fjords appear to be driven by landscape structure and transport dynamics. The bottom topography within the sampled region of Harriman Fjord is highly variable and includes a glacial moraine. This moraine appears to facilitate tidal upwelling. On an incoming tide, warmer, more saline ocean waters enter over the moraine and force the relatively cooler, fresher and more glacially influenced waters towards the surface as they converge. This phenomenon was evident in the data as a cold wedge at shallow depths (Fig. 4C), prominent at most locations used by Kittlitz's murrelet. This association with moraine upwelling events is further supported by the higher abundance of Kittlitz's murrelets during the incoming high tide phase. Although these locations were in fact farther from the moraine
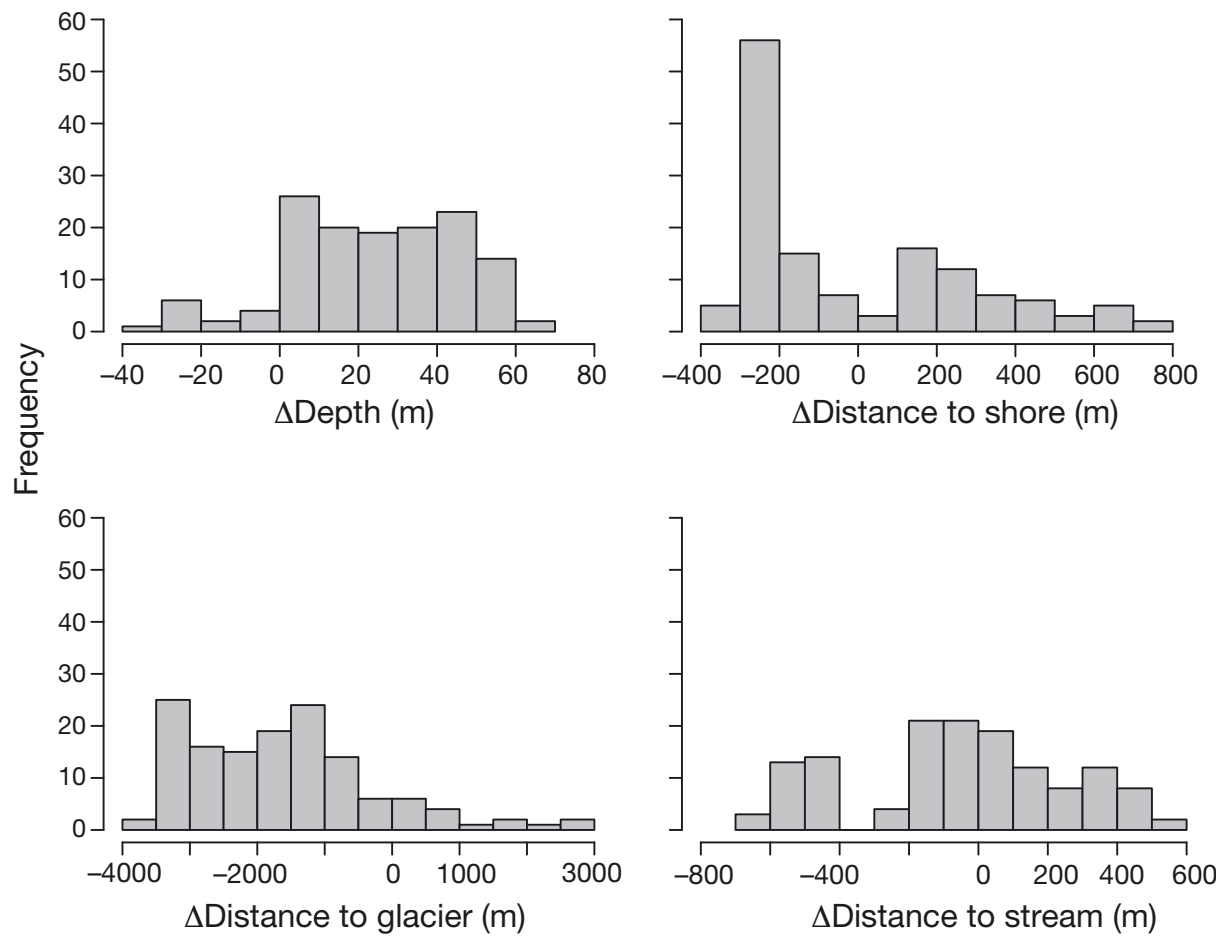

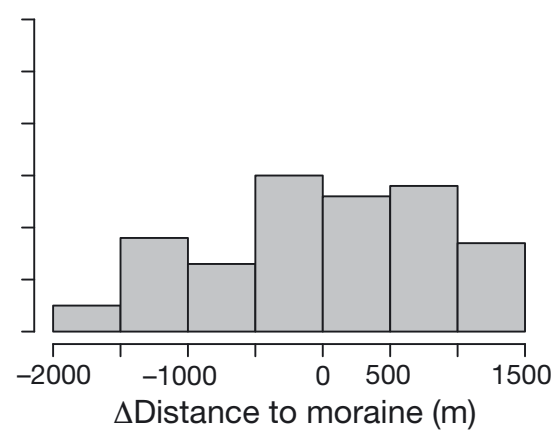

Fig. 5. Frequency distributions of the differences between Kittlitz's murrelet habitat use locations and average available habitat values for 5 landscape feature variables within Harriman Fjord, Alaska, July 2008. A positive difference in depth indicates Kittlitz's murrelets were observed in shallower waters than the average available habitat (depth measured as negative), and positive differences for distance variables indicate Kittlitz's murrelets were observed farther from a feature than the average available habitat 
Table 4. Point estimates, SE, and probability values of parameters included in global generalized linear model A (with distance to moraine parameter) and model B (without distance to moraine parameter) describing Kittlitz's murrelet habitat use in Heather Bay, Alaska, July 2008

\begin{tabular}{|lcccl|}
\hline Parameter & Estimate & SE & $Z$-statistic & $\mathrm{p}(>|Z|)$ \\
\hline Model A & & & & \\
Depth & -0.013 & 0.04 & -0.32 & 0.75 \\
Distance to shore & -5.95 & 6.96 & -0.86 & 0.39 \\
Distance to moraine & -2.37 & 0.74 & -3.22 & 0.0013 \\
Distance to stream & -0.27 & 2.72 & -0.10 & 0.92 \\
TDPS & 0.37 & 0.41 & 0.91 & 0.36 \\
Model B & & & & \\
Depth & 0.38 & 0.14 & 2.63 & 0.0085 \\
Distance to shore & -22.74 & 8.83 & -2.28 & 0.010 \\
Distance to stream & -1.52 & 1.91 & -0.79 & 0.43 \\
TDPS & 0.68 & 0.46 & 1.46 & 0.14 \\
\hline
\end{tabular}

than the average available habitat, this could be because the sampling area was centered directly over the moraine, resulting in a very short average distance $(\sim 1000 \mathrm{~m})$ between the moraine and the available habitat. Alternatively, this relationship may indicate the spatial scale of the upwelling events. Although the tidal upwelling appears to be driven by the moraine feature, optimal upwelling conditions may exist a certain distance away from the moraine, and it is this distance and time that allows incoming warm, saline water to displace the cooler, fresher, more glacially influenced waters.

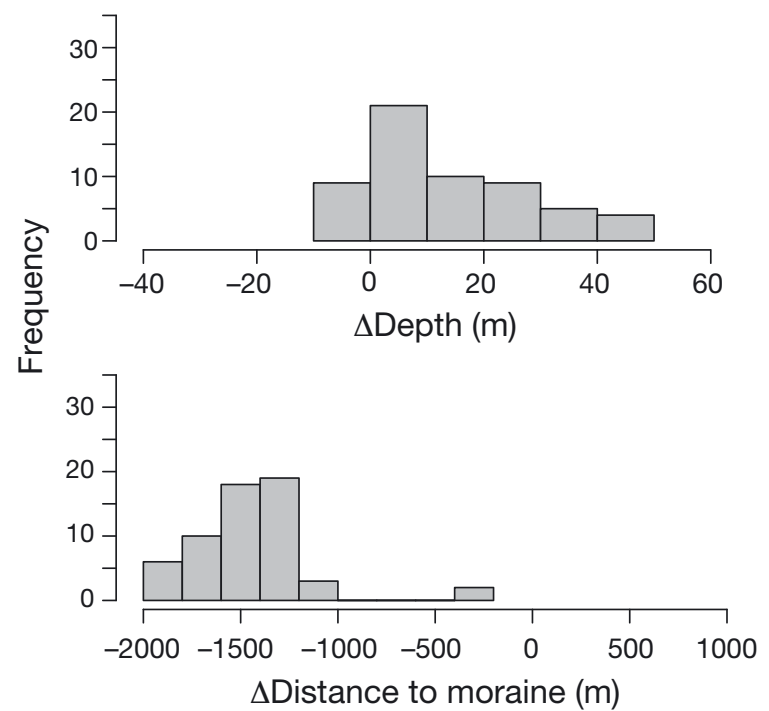

In contrast to the sampling region in Harriman Fjord, Heather Bay contains no tidewater glaciers. However, the fjord is still strongly influenced by Columbia Glacier in neighboring Columbia Bay. Columbia Glacier is currently in drastic retreat (Walter et al. 2010) and produces a large volume of icebergs calved from its receding face. A submerged moraine $6.5 \mathrm{~km}$ from the mouth of Columbia Bay serves as a dam, creating a densely packed pool of trapped icebergs $\sim 12 \mathrm{~km}$ long. At the head of adjoining Heather Bay, an intertidal moraine separates Columbia Bay's iceberg pool from the warmer waters of Heather Bay. These calved icebergs, combined with the cold $\left(\sim 1^{\circ} \mathrm{C}\right)$ pool water, breach the Heather Bay moraine during each incoming tide and pour into Heather Bay. In striking contrast to the observed upwelling in Harriman Fjord, the cold, fresh glacial water enters and remains at the surface of the water column in Heather Bay (Fig. 4D). This TDPS best matched locations where we observed Kittlitz's murrelets within Heather Bay, where surface waters were dramatically cooler than underlying water.

The fact that TDPSs seem to be important in describing Kittlitz's murrelet habitat use suggests that these water column characteristics have some effect on prey availability. Temperature gradients can affect the distribution of fish and zooplankton (e.g. Coyle \& Pinchuk 2005, Speckman et al. 2005), and create concentrations of prey within and slightly above or below water masses of different tempera-
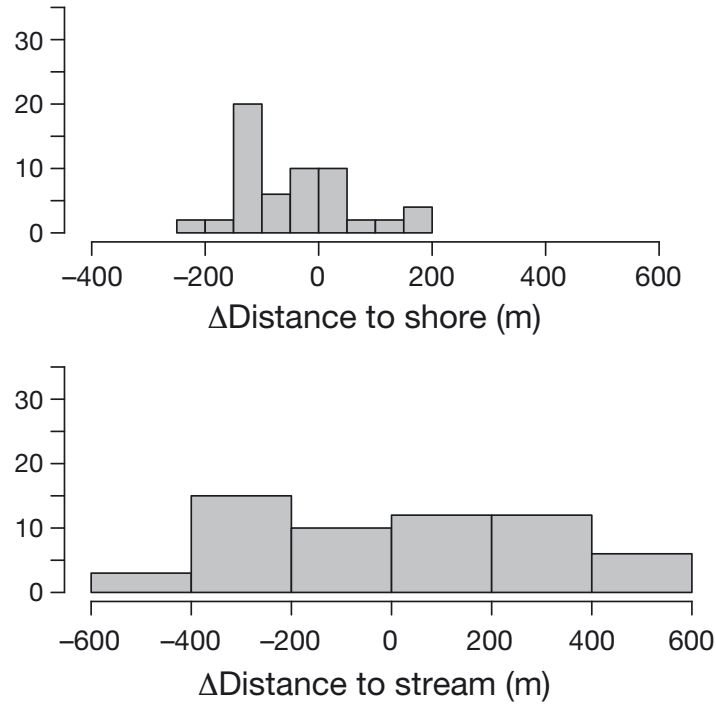

Fig. 6. Frequency distributions of the differences between Kittlitz's murrelet habitat use locations and average available habitat values for 4 landscape feature variables within Heather Bay, Alaska, July 2008. A positive difference in depth indicates that Kittlitz's murrelets were observed in shallower waters than the average available habitat (depth measured as negative), and positive differences for distance variables indicate that Kittlitz's murrelets were observed farther from a feature than the average available habitat 
tures (e.g. Haney 1988, Frank et al. 1989). Additionally, in glacial fjord systems macrozooplankton species may avoid the colder, less saline, more turbid waters when entering the system, resulting in high concentrations of macrozooplankton near these interface points (Weslawski et al. 1995). Therefore, the interface between water masses may aggregate prey species not only at certain locations within the fjord, but also at certain depths and times (i.e. tidal phases) at particular locations. These distinct patterns could ultimately allow Kittlitz's murrelets, which are 'persistent hotspot' foragers (Day \& Nigro 2000, Stephensen 2009), to focus their foraging efforts on predictable prey hotspots both spatially within the fjord and vertically within the water column.

A substantial proportion of the remaining global population of Kittlitz's murrelets is found in the glacial fiords of PWS during the summer months (USFWS 2010). Within PWS, Harriman Fjord and Heather Bay can host relatively high densities of this rare seabird (Kuletz et al. 2011). Our research shows that entirely different dynamics may render each of these areas a reliable Kittlitz's murrelet foraging hotspot. Both systems, however, are heavily dependent on glacial input. Considering that more than $98 \%$ of tidewater glaciers in Alaska are now receding (Molnia 2007), glacial influence on these important Kittlitz's murrelet refugia is likely to change significantly in coming decades. Given the tight association between Kittlitz's murrelets and coastal glacial features, reduction in the effects of glacial influx on the water column in fjords will likely degrade the quality of Kittlitz's murrelet habitat. For a species with already low overall population numbers, further reductions in survival or productivity rates from a reduction in foraging habitat quality could prove devastating to future Kittlitz's murrelet populations.

Acknowledgements. This work was funded by the Earthwatch Institute and partially supported by the National Science Foundation-sponsored IGERT: Offshore Wind Energy, Engineering, Environmental Science and Policy (Grant Number 1068864). The US Fish and Wildlife Service Migratory Bird Management Program-Anchorage, AK, provided survey vessels and equipment. We thank A. Robbins and N. Nelson for their dedicated field support and help with data collection. Additionally, we thank the Earthwatch volunteers A. Adley, S. Arthur, D. Brindle, M. Rivera, D. Smith, R. Speer, and J. Stayner for their help with data collection. M. Leckie (University of Massachusetts) and J. Brigham-Grette (University of Massachusetts) provided helpful insight into interpreting temperature-depth profiles, and possible tidewater glacier mechanisms that could have caused the observed profiles. Two anonymous reviewers greatly enhanced the quality of this manuscript.

\section{LITERATURE CITED}

Alldredge AL, Hamner WM (1980) Recurring aggregation of zooplankton by a tidal current. Estuar Coast Mar Sci 10: 31-37

Allen SE, Vindeirinho C, Thomson RE, Foreman MGG, Mackas DL (2001) Physical and biological processes over a submarine canyon during an upwelling event. Can J Fish Aquat Sci 58:671-684

Allyn AJ, McKnight A, Robbins AMC, Sullivan KM, Irons DB (2008) Distribution patterns and behavior of Kittlitz's murrelets Brachyramphus brevirostris with links to oceanographic characteristics in Heather Bay, Alaska, 2006 and 2007. Unpublished report submitted to US Fish and Wildlife Service, Migratory Bird Program, Anchorage, AK

Arimitsu M, Piatt JF, Romano MD, Van Pelt TI (2011) Status and distribution of the Kittlitz's murrelet Brachyramphus brevirostris in Kenai Fjords, Alaska. Mar Ornithol 39: $13-22$

Arimitsu ML, Piatt JF, Madison EN, Conaway JS, Hillgruber N (2012) Oceanographic gradients and seabird prey community dynamics in glacial fjords. Fish Oceanogr 21: 148-169

Baddeley A, Turner R (2005) Spatstat: an R package for analyzing spatial point patterns. J Stat Softw 12:1-42

Belkin IM, Cornillon PC, Sherman K (2009) Fronts in large marine ecosystems. Prog Oceanogr 81:223-236

Bivand R, Altman M, Anselin L, Assuncao R and others (2012) spdep: spatial dependence: weighting schemes, statistics and models. $\mathrm{R}$ package version 0.5-45. Available at http://CRAN.R-project.org/package=spdep

Breslow NE, Day NE (1980) Statistical methods in cancer research, Vol I: the analysis of case-control studies. International Agency for Research on Cancer, Lyon

Chastel O, Weimerskirch H, Jouventin P (1995) Body condition and seabird reproductive performance: a study of three petrel species. Ecology 76:2240-2246

Compton BW, Rhymer JM, McCollough M (2002) Habitat selection by wood turtles (Clemmys insculpta): an application of paired logistic regression. Ecology 83: 833-843

- Cooney RT, Allen JR, Bishop MA, Eslinger DL and others (2001) Ecosystem controls of juvenile pink salmon (Onchorynchus gorbuscha) and Pacific herring (Clupea pallasi) populations in Prince William Sound, Alaska. Fish Oceanogr 10:1-13

> Coyle KO, Pinchuk AI (2005) Seasonal cross-shelf distribution of major zooplankton taxa on the northern Gulf of Alaska shelf relative to water mass properties, species depth preferences and vertical migration behavior. Deep-Sea Res II 52:217-245

> Day RH, Byrd GV (1989) Food habits of the whiskered auklet at Buldir Island, Alaska. Condor 91:65-72

Day RH, Nigro DA (2000) Feeding ecology of Kittlitz's and marbled murrelets in Prince William Sound, Alaska. Waterbirds 23:1-14

Day RH, Kuletz KJ, Nigro DA (1999) Kittlitz's murrelet (Brachyramphus brevirostris). In: Poole A, Gill F (eds) The birds of North America, No. 435. The Birds of North America, Philadelphia, PA

> Durazo R (1998) Seabird observations at a tidal mixing front in the Irish Sea. Estuar Coast Shelf Sci 47:153-164

ESRI (Environmental Systems Resource Institute) (2008) ArcMap 9.3. ESRI, Redlands, CA 
Etherington LL, Hooge PN, Hooge ER, Hill DF (2007) Oceanography of Glacier Bay, Alaska: implications for biological patterns in a glacial fjord estuary. Estuaries Coasts 30:927-944

> Frank KT, Page FH, McRuer JK (1989) Hydrographic effects on the vertical distribution of haddock (Melanogrammus aeglefinus) eggs and larvae on the southwestern Scotian Shelf. Can J Fish Aquat Sci 46:S82-S92

Haney JF (1988) Diel patterns of zooplankton behavior. Bull Mar Sci 43:583-603

Hobson KA (1986) Predation on the Pacific sand lance Ammodytes hexapterus (Pisces: Ammodytidae), during the transition between day and night in southeastern Alaska. Copeia 1986:223-226

Hobson KA, Piatt JF, Pitocchelli J (1994) Using stable isotopes to determine seabird trophic relationships. J Anim Ecol 63:786-798

Hunt GL, Schneider DC (1987) Scale-dependent processes in the physical and biological environment of marine birds. In: Croaxall JP (ed) Seabirds: feeding ecology and role in marine ecosystems. Cambridge University Press, Cambridge, p 7-41

- Hunt GL, Russell RW, Coyle KO, Weingartner T (1998) Comparative foraging ecology of planktivorous auklets in relation to ocean physics and prey availability. Mar Ecol Prog Ser 167:241-259

Jodice PGR, Collopy MW (1999) Diving and foraging patterns of marbled murrelets (Brachyramphus marmoratus): testing predictions from optimal-breathing models. Can J Zool 77:1409-1418

Kaler RS, Kenney LA, Sandercock BK (2009) Breeding ecology of Kittlitz's murrelets at Agattu Island, Aleutian Islands, Alaska. Waterbirds 32:363-479

Kissling ML, Reid M, Lukacs PM, Gende SM, Lewis SB (2007) Understanding abundance patterns of a declining seabird: implications for monitoring. Ecol Appl 17: 2164-2174

Kosmidis I (2010) brglm: bias reduction in binary-response GLMs. Available at www.ucl.ac.uk/ ucakiko/software. html

Kuletz KJ, Stephensen SW, Irons DB, Labunski EA, Brenneman KM (2003) Changes in the distribution and abundance of Kittlitz's murrelets (Brachyramphus brevirostris) relative to glacial recession in Prince William Sound, Alaska. Mar Ornithol 31:133-140

Kuletz KJ, Nations CS, Manly B, Allyn A, Irons DB, McKnight A (2011) Distribution, abundance, and population trends of the Kittlitz's murrelet Brachyramphus brevirostris in Prince William Sound, Alaska. Mar Ornithol 39: 97-109

Lethcoe N (1987) An observer's guide to the glaciers of Prince William Sound, Alaska. Prince William Sound Books, Valdez, AK

MacArthur RH, Pianka ER (1966) On the optimal use of a patchy environment. Am Nat 100:603-609

Mann KH, Lazier JRN (2006) Dynamics of marine ecosystems: biological-physical interactions in the oceans, 3rd edn. Wiley-Blackwell, Malden, MA

Molnia BF (2007) Late nineteenth to early twenty-first century behavior of Alaskan glaciers as indicators of changing regional climate. Global Planet Change 56:23-56

Pebesma EJ (2004) Multivariable geostatistics in S: the gstat package. Comput Geosci 30:683-691

Peery MZ, Newman SH, Storlazzi CD, Beissinger SR (2009) Meeting reproductive demands in a dynamic upwelling system: foraging strategies of a pursuit-diving seabird, the marbled murrelet. Condor 111:120-134

Pelletier L, Kato A, Chiaradia A, Ropert-Coudert Y (2012) Can thermoclines be a cue to prey distribution for marine top predators? A case study with little penguins. PLoS ONE 7:e31768

Piatt JF, Arimitsu M, Drew G, Madison EN, Bodkin J, Romano MD (2011) Status and trend of the Kittlitz's murrelet Brachyramphus brevirostris in Glacier Bay, Alaska. Mar Ornithol 39:65-75

R Core Development Team (2010) R: a language and environment for statistical computing. R Foundation for Statistical Computing, Vienna. Available at www.rproject.org/

Schneider DC (1990) Seabirds and fronts: a brief overview. Polar Res 8:17-21

Seabird Electronics (2012) Seasoft V2:SBE data processing user's manual. Available at www.seabird.com/pdf_ documents/manuals/SBEDataProcessing_7.21k

Spear LB, Balance LT, Ainley DG (2001) Response of seabirds to thermal boundaries in the tropical Pacific: the thermocline versus the Equatorial Front. Mar Ecol Prog Ser 219:275-289

Speckman SG, Springer AM, Piatt JF, Thomas DL (2000) Temporal variability in abundance of marbled murrelets at sea in Southeast Alaska. Waterbirds 23:364-377

Speckman SG, Piatt JF, Minte-vera C, Parrish J (2005) Parallel structure among environmental gradients and three trophic levels in a subarctic estuary. Prog Oceanogr 66: 25-65

Stephens DW, Krebs JR (1986) Foraging theory. Princeton University Press, Princeton, NJ

Stephensen SW (2009) A comparison of preferred habitats of Kittlitz's and marbled murrelets in Harriman Fiord Prince William Sound, Alaska. MS thesis, University of AlaskaAnchorage, Anchorage, AK

Stewart RH (2008) Introduction to physical oceanography. Texas A\&M University, College Station, TX. Available at http://oceanworld.tamu.edu/resources/ocng_textbook/ contents.html

USDA Forest Service (2008) Freshwater streams line file and saltwater shoreline polygons. Available at http://fsgeodata. fs.fed.us/rastergateway/alaska/chugach/themes.php

USFWS (US Fish and Wildlife Service) (2010) US Fish and Wildlife Service Status assessment and listing priority assignment form for Kittlitz's murrelet. US Fish and Wildlife Service, Anchorage, AK

van Etten J (2011) gdistance: distances and routes on geographical grids. R package version 1.1-1. Available at http://CRAN.R-project.org/package=gdistance

Walter F, O'Neel S, Mcnamara D, Pfeffer WT, Bassis JN, Fricker HA (2010) Iceberg calving during transition from grounded to floating ice: Columbia Glacier, Alaska. Geophys Res Lett 37:L15501.

Weslawski JM, Koszteyn J, Zajaczkowski M, Wiktor J, Kwasniewski S (1995) Fresh water in Svalbard fjord ecosystems. In: Skjoldal HR, Hopkins C, Erikstad KE, Leinnas HP (eds) Ecology of fjords and coastal waters. Elsevier, New York, NY, p 229-242

Wilson JG, Overland JE (1986) Meterology. In: Hood DW, Zimmerman ST (eds) The Gulf of Alaska: physical environment and biological resources. US Department of Commerce, National Oceanic and Atmospheric Administration, Ocean Assessments Division, Anchorage, AK, p 31-54 
Appendix 1. Supplemental information for survey design (Table A1) and parameter values used to develop candidate temperature-depth profile models (Table A2)

Table A1. Date (in 2008), area, Kittlitz's murrelet density region, number of transects surveyed, and CTD casts completed in Heather Bay and Harriman Fjord, Alaska, USA

\begin{tabular}{|lllcc|}
\hline Date & Fjord & $\begin{array}{c}\text { Kittlitz's murrelet } \\
\text { density region }\end{array}$ & $\begin{array}{c}\text { Number of } \\
\text { transects }\end{array}$ & $\begin{array}{c}\text { Number of } \\
\text { CTD casts }\end{array}$ \\
\hline 2 Jul & Heather Bay & High & 4 & 17 \\
5 Jul & Heather Bay & Kow & 4 & 23 \\
10 Jul & Harriman Fjord & High & 2 & 12 \\
& Harriman Fjord & Kow & 2 & 9 \\
17 Jul & Harriman Fjord & High & 4 & 13 \\
20 Jul & Heather Bay & High & 7 & 13 \\
& Heather Bay & Kow & 4 & 10 \\
& Harriman Fjord & High & 3 & 7 \\
& Harriman Fjord & Kow & 2 & \\
\hline
\end{tabular}

Table A2. Parameter descriptions and range of possible values used in constructing candidate temperature-depth profile models with linear piece-wise function

\begin{tabular}{|ll|}
\hline Parameter & Possible values \\
\hline Temperature at 1st inflection & $0,2,-2,4,-4$ \\
Depth at 1st inflection & $2.5,5,7.5,10$ \\
Temperature at 2nd inflection & $0,2,-2,4,-4$ \\
Depth at 2nd inflection & $10,15,20$ \\
End temperature & $0,2,-2,4,-4$ \\
End depth & 25 \\
\hline
\end{tabular}

Editorial responsibility: Jacob González-Solís, Barcelona, Spain
Submitted: January 27, 2012; Accepted: July 1, 2012 Proofs received from author(s): October 8, 2012 